\title{
Contrasted survival under field or controlled conditions displays associations between mRNA levels of candidate genes and response to OsHV-1 infection in the Pacific oyster Crassostrea gigas
}

\author{
Julien Normand $^{\mathrm{a}, \mathrm{b}}$, Ronghua Li ${ }^{\mathrm{a}, 1}$, Virgile Quillien ${ }^{\mathrm{a}}$, Jean-Louis Nicolas ${ }^{\mathrm{a}}$, Pierre Boudry $^{\mathrm{a}}$, \\ Fabrice Pernet ${ }^{\mathrm{c}, 2}$, Arnaud Huvet ${ }^{\mathrm{a}, \mathrm{d}, \text { * }}$
}

\author{
a Ifremer, UMR 6539, Laboratoire des Sciences de l'Environnement Marin, Zl de la Pointe du Diable, CS 10070, \\ 29280 Plouzané, France. \\ ${ }^{b}$ Ifremer, Station de Port en Bessin, LER/N, 14520 Port-en-Bessin, France. \\ c Ifremer, Laboratoire Environnement Ressources Languedoc-Roussillon, Pôle Mer et Lagunes, Bd Jean Monnet, \\ BP 171, 34203 Sète Cedex, France. \\ d Ifremer, Station de la Trinité sur Mer, LER/MPL, 56470 La Trinité Sur Mer, France. \\ ${ }_{1}^{1}$ Present address : School of Marine Science of Ningbo University, Ningbo 315211, China \\ 2 Present address : Ifremer, UMR 6539, Laboratoire des Sciences de I'Environnement Marin, BP 70, 29280 \\ Plouzané, France
}

\author{
*: Corresponding author : Arnaud Huvet, tel.: + 33298224693 ; fax: + 33298224653 ; \\ email address : ahuvet@ifremer.fr
}

\begin{abstract}
:
Pacific oyster Crassostrea gigas suffers from chronic or sporadic mortality outbreaks worldwide, resulting from infectious diseases and/or physiological disorders triggered by environmental factors. Since 2008, ostreid herpesvirus OsHV-1 $\mu$ Var has been identified as the main agent responsible for mass mortality of juvenile oysters in Europe. Previous studies of genome-wide expression profiling have provided candidate genes that potentially contribute to genetically-based resistance to summer mortality. To assess their value in determining resistance to the juvenile mass mortality that has occurred in France since 2008, we analyzed the expression of 17 candidate genes in an experimental infection by OsHV-1 $\mu \mathrm{Var}$, and in an in vivo field experiment. Individual quantification of mRNA levels of 10 out of the 17 targeted genes revealed significant variation, of which 7 genes were showed differences between conditions that created significant differences in mortality, and 6 depended on the number of OsHV-1 genome copies individually quantified in mantle tissue. Complex SOD metalloenzymes known to be part of the antioxidant defense strategies may at least partly determine susceptibility or resistance to OsHV-1-associated mortality. Furthermore, inhibitor 2 of NF-KB, termed CglkB2, exhibited highly significant variation of mRNA levels depending on OsHV-1 load in both experiments, suggesting its implication in the antiviral immune response of $C$. gigas. Our results suggest that $\mathrm{Cg} / \mathrm{kB} 2$ expression would make a good starting point for further functional research and that it could be used in marker-assisted selection.
\end{abstract}

Keywords : Mollusca ; Gene expression profiling ; Inhibitor of KB ; Summer mortality ; Ostreid herpesvirus 


\section{Introduction}

Mass mortalities of oysters have been reported for decades in many countries throughout the world but, in many cases, no precise pathological causal factors were identified (reviewed in Samain and McCombie 2008). Sporadic outbreaks usually occur during the summer months, when oysters are undergoing sexual maturation, and result from a combination of the effects of pathogens, environmental factors and host physiological and genetic characteristics (Samain and McCombie 2008). Indeed, taking advantage of the high heritability estimated for resistance to summer mortality (Boudry et al., 2008; Dégremont et al., 2007, 2010), lines of oysters selected in 2001 for resistance ("R") or susceptibility ("S") to summer mortality were examined by genome-wide expression profiling studies (Huvet et al., 2004; Fleury et al., 2010; Fleury and Huvet, 2012). Genes identified as differentially expressed between these two groups mainly fall into the categories: energy metabolism (carbohydrates, lipids), reproduction, response to stress and immune response. Besides the energetic requirements of reproduction, which can lead to a phase of energetic weakness for oysters, these studies highlighted antioxidant defense and signaling in innate immunity as constitutive pathways involved in resistance to summer mortality. Indeed, the kinetics of mRNA levels, especially for molecules regulating the NF-KB (nuclear factor kappa-light-chain-enhancer of activated B cells) signaling pathway, assayed under field conditions before a mortality peak, suggested that resistant oysters had the capacity to modulate signaling in innate immunity, whereas susceptible oysters did not (Fleury and Huvet, 2012). Additionally, a few of these differentially expressed candidate genes were also found to be in statistically significant co-location with the first Quantitative Trait Loci (QTL) identified for resistance to OsHV-1-associated summer mortality (Sauvage et al., 2010).

Since spring 2008, a new pattern of mass mortality has occurred of $C$. gigas of less than one year old along all coasts of France. These mortality episodes are different from the previous sporadic phenomenon by their higher intensity and more widespread geographic distribution (Jolivel and Fleury, 2012). Oysters analyzed during mortality outbreaks in 2008 showed an elevated prevalence of the ostreid herpesvirus OsHV-1 compared with previous years (Segarra et al., 2010). These authors characterized a genotype of OsHV-1 not previously reported, which was named OsHV-1 $\mu$ Var. Official sample collection from the National Reference Laboratory in France revealed that the OsHV-1 $\mu$ Var genotype has replaced the previously observed OsHV-1 as almost the only strain detected during oyster mortality events in France since 2008 (Renault et al., 2012). Experimental infection trials indeed confirmed the high pathogenicity of OsHV-1 $\mu$ Var (Schikorski et al., 2011a,b). Finally, a recent paper showed that the selection previously made for resistance to summer mortality, leading to the $R$ and $S$ lines presented above, still conferred a strong advantage to descendant batches in this new mortality context when survival of juvenile C. gigas was tested in 2009 (Dégremont, 2011). The highest survival reported for R batches (95\% against $6 \%$ for the $S$ ) was associated with herpesvirus resistance in $\mathrm{R}$ oysters displayed by a low OsHV-1 prevalence in oyster tissues (Dégremont, 2011).

The main objective of the present study was to examine the expression profiles of the 17 previously-identified candidate genes in the novel context of mass mortalities of young oysters. The expression profiles of these candidate genes were evaluated in oysters (1) injected with OsHV-1 $\mu$ Var in the laboratory, and (2) naturally exposed to the disease in the Thau lagoon, a farming area where mortalities are among the highest in France (Jolivel and Fleury, 2012). Variation of mRNA levels was explored by comparing expression between conditions that created a significant difference in mortality, and by looking at the relationship between gene expression and the OsHV-1 load. The present study will help us to prioritize these candidates for further functional and genetic studies of resistance to summer mortality. 


\section{Material and methods}

\subsection{Experiments}

\subsubsection{Exp. 1.}

This trial aimed to infect healthy oysters with OsHV-1 through intra-muscular injection of virulent inoculum obtained by filtering tissue homogenates from contaminated oysters (following Schikorski et al., 2011b). The control group consisted of oysters from the same experimental population but injected with non-virulent inoculum. Virulent and control non-virulent inocula were obtained by crushing the whole soft tissues of three oysters from two commercial stocks, one showing mortality in progress and the other not. Soft tissues were crushed on ice; homogenates were then diluted with sterile seawater $(1 \mathrm{~g}$ of fresh tissues for $40 \mathrm{~mL}$ ) and filtered through 0.1$\mu \mathrm{m}$ syringe filters to prevent bacterial transmission.

The oysters to be challenged were triploids purchased from a commercial hatchery. These had been produced by a cross between diploid females and tetraploid males in summer 2008 and then cultured in the Aber Benoit (Finistère, France). They were transferred at 8 months old to the Ifremer experimental facilities in Plouzané (Finistère, France) in March 2009 for acclimation. The oysters were then anesthetized as described by Suquet et al. (2009) and injected (see Saulnier et al. (2010) for details of the injection protocol) with $100 \mu$ inocula that were considered either virulent or non-virulent / very weakly virulent, corresponding to $2.10^{9}$ and $4.10^{6}$ copies of viral genome injected, respectively (quantified in the inocula by real-time PCR). After injection, oysters from challenged and control groups were divided into $2 \times 3$ batches of 45 individuals. Each batch was placed in a 20-L tank filled with 1- $\mu \mathrm{m}$ filtered seawater and maintained at $20^{\circ} \mathrm{C}$ with aeration and no seawater renewal.

Two and 6 days after injection, 10 live oysters were collected in each tank (to constitute 10 biological replicates per condition; 40 samples in total), opened and the entire flesh of each animal immediately frozen in liquid nitrogen, crushed to a fine powder at $-196^{\circ} \mathrm{C}$ with a Dangoumau mill and stored in liquid nitrogen until DNA and RNA extractions were performed. The remaining oysters in each group continued to be reared under the same experimental conditions. Mortality was estimated by counting live and dead individuals daily. Dead oysters were removed from the tanks after counting.

\subsubsection{Exp. 2.}

This experiment corresponds to "experiment 3" previously reported in Pernet et al. (2012) which initially was designed to test for rearing structures and sites effects on the mortality of juvenile oysters. As for Exp. 1, this trial used triploid oysters, produced by diploid $\times$ tetraploid crosses in summer 2008, which were purchased from a commercial hatchery. Juveniles were reared in the open sea close to the Thau lagoon. At this time, rearing conditions allowed these oysters to be maintained without any mortality, so that they were healthy at the start of the experiment. The 27 May 2010, these individuals were transferred to two different locations inside the lagoon that showed extremely closed environmental conditions (reported for seawater temperature in Pernet et al., 2012) as only separated by a maximum of two hundred and fifty meters, and 
deployed in three different combinations of rearing structure and placement, which gave three different experimental conditions (for details of the procedure see Pernet et al., 2012). One part of the experimental stock was placed within the farming area of Marseillan, in baskets (condition 1 ) or cemented on ropes (condition 2), both of which are common rearing methods in the Thau lagoon. The remaining individuals were kept in baskets outside the farming area of Marseillan, but within the Thau lagoon (condition 3).

At 8 (4 June 2010), 11 (7 June) and 15 (11 June) days after deployment, mortalities were estimated by counting live and dead oysters, and nine live individuals per condition were randomly sampled that constitute 9 biological replicates per condition ( 81 samples in total). The valves were opened and discarded, and the soft tissues of each animal was immediately frozen in liquid nitrogen, crushed to a fine powder at $-196^{\circ} \mathrm{C}$ with a Dangoumau mill and stored in liquid nitrogen until DNA and RNA extractions.

\subsection{Methods}

\subsubsection{Detection and quantification of OsHV-1}

Total DNA was extracted from oyster tissues as described in Schikorski et al. (2011a, b) for real-time PCR assay analyses. The detection and quantification of OsHV-1 DNA was carried out in triplicate using real-time PCR according to Pepin et al. (2008), with specific primers that amplified both reference and $\mu$ Var types. Briefly, absolute quantification of OsHV-1 DNA copies was carried out by comparing the Ct values obtained for tested samples with a standard curve based on a ten-fold dilution of a stock solution of OsHV-1 genomic DNA ( $5 \times 10^{6}$ copies/ $\left./ \mathrm{LL}\right)$ extracted from purified virus particles. In Exp. 1, the results were expressed as virus DNA copy numbers per ng total DNA. Standardization of OsHV-1 genomic DNA quantity was reached using DNA concentrations measured using an ND-1000 spectrophotometer (Nanodrop Technologies) at $260 \mathrm{~nm}$ with the conversion factor of $1 \mathrm{OD}=50 \mu \mathrm{g} / \mathrm{mL}$ DNA. In Exp. 2, the quantity of OsHV-1 genomic DNA was expressed per mg of wet tissues. Standardization was different between the two experiments, and better adapted in Exp. 1 (standardization being more accurate and stable per ng of extracted DNA), which was published between analyses of Exp. 2 in 2010 and those of Exp. 1 in 2011 (Schikorski et al., 2011b).

In both experiments, the estimates of OsHV-1 DNA copies were highly variable, and followed an asymmetric distribution that appeared to be neither normal nor Poisson, even after classical normalization transformations. Values were consequently log-transformed and rounded down to the nearest whole number to produce a discrete "virus-load" class variable composed of 5 classes for Exp. 1 and 7 classes for Exp. 2:

- Exp. 1: class 1: from 0 to $10^{1}$ copies of viral genome per ng of oyster DNA, class 2: from $10^{1}$ to $10^{2}$ copies / ng DNA, class 3: from $10^{2}$ to $10^{3}$ copies / ng DNA, class 4: from $10^{3}$ to $10^{4}$ copies / ng DNA, class 5: from $10^{4}$ to $10^{5}$ copies / ng DNA.

- $\quad$ Exp. 2: class 1: from 0 to $10^{1}$ copies of viral genome per mg of dry tissues, class 2: from $10^{1}$ to $10^{2}$ copies / mg, class 3: from $10^{2}$ to $10^{3}$ copies / mg, class 4 : from $10^{3}$ to $10^{4}$ copies / mg, class 5: from $10^{4}$ to $10^{5}$ copies / mg, class 6 : from $10^{5}$ to $10^{6}$ copies / mg, class 7: from $10^{6}$ to $10^{7}$ copies / mg. 


\subsubsection{Gene expression analysis by real-time PCR}

Total RNA of each sample (121 samples in total) was isolated using the Extract-all (Eurobio) procedure at a concentration of $1 \mathrm{ml} / 50 \mathrm{mg}$ powder. Samples were then treated with DNAse I $(1 \mathrm{U} / \mu \mathrm{g}$ total RNA, Sigma) to prevent DNA contamination. RNA quality was assessed using RNA nano chips and Agilent RNA 6000 nano reagents (Agilent Technologies, Waldbronn, Germany) according to manufacturer's instructions. RNA concentrations were measured using an ND-1000 spectrophotometer (Nanodrop Technologies) at $260 \mathrm{~nm}$, using the conversion factor $1 \mathrm{OD}=40 \mu \mathrm{g} / \mathrm{mL}$ RNA. From $2 \mu \mathrm{g}$ total RNA, RT-PCR amplifications were carried out as described in Fabioux et al. (2004). Briefly, real-time PCR amplifications were carried out in triplicate with $5 \mu \mathrm{L}$ cDNA (1/10 dilution) in a total volume of $15 \mu \mathrm{L}$ with the iQ SYBR Green Supermix (Biorad) using an Icycler (Biorad). Each run included a cDNA reference, negative controls (each total RNA sample with DNAse I treatment), and blank controls (water) analyzed for each primer pair. For the 17 mRNA investigated, PCR efficiency (E) was estimated for each primer pair by determining the slopes of standard curves obtained from serial dilution analysis, to ensure that $E$ ranged from 98 to $100 \%$. Primer names, accession numbers, PCR efficiencies and sequences are listed in Table S1 (Supplementary material). In Exp. 1, amplification of actin cDNA (primers in Huvet et al., 2012) was performed to validate the steady-state level of expression of a housekeeping gene and to provide an internal control for gene expression. Indeed, no significant differences in Ct values were observed for actin mRNA level for any of the factors examined (class OsHV-1: $F_{4,113}=0.6, P=0.66$; inoculum: $F_{1,113}=0.26, P=0.61$; day: $F_{1,113}=0.09, P=0.76$; day $\times$ inoculum: $F_{1,113}=0.75, P=0.39$ ). In Exp. 2 , actin mRNA levels revealed significant variation at the $5 \%$ level between sampling days. Therefore, the relative mRNA levels of the target genes were normalized to those of manganese-superoxide dismutase (Mn-SOD) using specific primers (Table S1) designed from C. gigas Mn-SOD sequence (Park et al., 2009) as no significant difference of $\mathrm{Ct}$ values was observed for $M n-S O D$ between conditions of experimental treatment (class OsHV-1: $F_{6,79}=1.29, \mathrm{P}=0.27$; condition: $F_{2,79}=$ 2.24, $\mathrm{P}=0.11$; day: $\mathrm{F}_{2,79}=1.25, \mathrm{P}=0.29$; day $\times$ condition: $\left.\mathrm{F}_{4,79}=1.10, \mathrm{P}=0.37\right)$. The relative mRNA levels of a studied gene "i" are consequently expressed in arbitrary unit as $2^{-\Delta \Lambda C t}$ (Pfaffl, 2001 ) with $\Delta \mathrm{Ct}=\mathrm{Ct}$ (i) $-\mathrm{Ct}$ (actin or $\mathrm{Mn}-\mathrm{SOD}$ ) and $\Delta \Delta \mathrm{Ct}=\Delta \mathrm{Ct}$ of $\mathrm{cDNA}$ sample $-\Delta \mathrm{Ct}$ of the reference cDNA. Finally, gene expression quantification values were log-transformed to ensure normality of the data.

\subsubsection{Data analyses}

Analyses first aimed to qualify the effects of experimental conditions (inoculum and day postinjection in Exp. 1; rearing condition and day post-deployment in Exp. 2) on mortality probabilities. The following logistic models were fitted to the data using the GENMOD procedure in SAS, employing a logit link function and a binomial distribution (Zelterman, 2002):

Exp. 1: logit $\left(\pi_{\text {mortality }}\right)=$ inoculum + day + inoculum $\times$ day

Exp. 2: logit $\left(\pi_{\text {mortality }}\right)=$ condition + day + condition $\times$ day 
A Chi-square test was performed to test for potential effects of explanatory variables included in the model, and odds ratios were calculated, allowing a comparison of the risk factor of mortality associated with inoculum (Exp. 1) or rearing conditions (Exp. 2) (Zelterman, 2002).

The same method was employed for analyzing the effects of experimental conditions on the probability that one individual would fall into one particular class of OsHV-1 load. For each experiment, we fitted the log-linear model of the independence of experimentally tested effects and counts distribution by OsHV-1 class. Due to the fact that (1) sample size for detection and quantification of pathogen was limited and (2) that a large count in one category (OsHV-1 class) was associated with smaller counts in all of the other cells, we employed multivariate distribution to model these correlated counts. For this, we used the GENMOD procedure in SAS, employing a logit link function and a multinomial distribution (Zelterman, 2002).

Exp. 1: logit $\left(\Pi_{\text {counts by OsHV-1 class }}\right)=$ inoculum + day + inoculum $\times$ day

Exp. 2: $\log i t\left(\pi_{\text {counts by } \mathrm{OsHV}-1 \text { class }}\right)=$ condition + day + condition $\times$ day

The hypothesis of the independency of counts per class of viral infection was finally tested through the use of Chi-square test.

The second step of analyses focused on modeling and testing the effects of experimental conditions and OsHV-1 infection on gene expression. The following models were implemented using PROC GLM in SAS, adding a least-squares (LS) means statement for post-hoc tests:

Exp. 1: Gene expression $=$ Class OsHV $-1+$ inoculum + day + inoculum $\times$ day

Exp. 2: Gene expression = Class OsHV $-1+$ condition + day + condition $\times$ day

When interaction effect appeared non-significant, this term was removed from the model to test for single-order effects alone.

\section{Results}

\subsection{Mortality and OsHV-1 load}

\subsubsection{Exp. 1.}

The first mortality was observed 3 days post-injection in challenged oysters. Mortalities increased regularly over time but were moderate overall and appeared significantly higher for oysters injected with virulent inoculum compared with control oysters (inoculum: $\mathrm{khi}^{2}{ }_{1,1}=12.7, \mathrm{P}$ $=0.0004$; day: $\mathrm{khi}^{2}{ }_{1,6}=29.18, \mathrm{P}<0.0001$; inoculum $\times$ day: $\left.\mathrm{khi}^{2}{ }_{1,6}=0.45, \mathrm{P}=0.0004\right)$. Out of a total of 60 oysters per treatment, nine oysters (15\%) injected with virulent inoculum died during the 7 -day challenge compared with only one control oyster $(<2 \%)$.

The effects of inoculum, day and inoculum $\times$ day were all found to be significant (inoculum: $\mathrm{khi}^{2}{ }_{1,4}=188.1, \mathrm{P}<0.0001$; day: $\mathrm{khi}^{2}{ }_{1,4}=179.6, \mathrm{P}<0.0001$; inoculum $\times$ day: $\mathrm{khi}^{2}{ }_{1,4}=12.6, \mathrm{P}=$ 0.0004 ) on OsHV-1 load. The OsHV-1 load was higher for oysters injected with the virulent inoculum (68\% showed more than 10 copies of viral genome per ng DNA, corresponding to our class 2 and above) compared with the control group (7\%) (Fig. 1). At day 2 post-injection, $7 \%$ of 
the oysters injected with the virulent inoculum presented a very high number of viral genomic copies (more than $10^{4}$ copies per ng DNA, corresponding to our class 5 ) whereas no oysters of the control group presented more than $10^{2}$ copies of the OsHV-1 genome per ng DNA. After day 2 , the estimated numbers of viral genomic copies decreased: the proportion of oysters presenting less than 10 OsHV-1 genome copies per ng DNA (class 1 ) was $53 \%$ for the injected oysters and $100 \%$ for control oysters.

\subsubsection{Exp. 2.}

Mortalities were found to be statistically influenced by day and rearing condition (rearing condition: $\mathrm{khi}_{2,4}{ }_{2,4}=841.76, \mathrm{P}<0.0001$; day: $\mathrm{khi}^{2}{ }_{1,4}=626.50, \mathrm{P}<0.0001$; rearing condition $\times$ day: $\mathrm{khi}_{2,4}=4.28, \mathrm{P}=0.112$ ). Disease severely affected oysters reared in baskets inside the farming area (condition 1) up to a mean mortality rate of $76 \%$ at the end of the 15-day experiment. Only $8 \%$ of the oysters fixed on ropes at the same location died (condition 2), and $0.3 \%$ of the oysters reared outside the farming area (condition 3) (Pernet et al., 2012). Contrast tests indicated a clear and significant contrast between condition 1 versus conditions 2 and 3 , based on high values of Odds Ratio (condition 1 vs. 2 : OR = 14.58; condition 1 vs. 3 : OR = 8.31). Low and non-significant contrast was found in mortality probability between conditions 2 and 3 (OR = $0.57)$.

Effects of rearing condition, day, and the interaction condition $\times$ day significantly affected the distribution of oysters per OsHV-1 infection class (rearing condition: $\mathrm{khi}^{2}{ }_{2,4}=1279, \mathrm{P}=0.0017$; day: $\mathrm{khi}^{2}{ }_{2,4}=59.07, \mathrm{P}<0.0001$; rearing condition $\times$ day: $\mathrm{khi}^{2}{ }_{2,4}=57.89, \mathrm{P}<0.0001$ ). The kinetic of virus DNA load followed the same temporal pattern in the three oyster groups, although the prevalence of highly infected individuals appeared much higher in conditions 1 and 2 than in condition 3 (Fig. 2). At day 8, the three groups showed that the majority of oysters were not infected, or presented less than 10 copies of viral DNA per mg tissue (6 out of 9 oysters tested, $5 / 9$ and $6 / 9$ for conditions 1,2 and 3 , respectively). The highest amounts of viral DNA were found at day 11 in conditions 1 and 2, with 8 out of 9 individuals showing more than $10^{2}$ copies. At the same time, all the individuals in condition 3 presented less than $10^{2}$ copies of viral DNA per mg of tissue. Finally, at day 15, high amounts of viral DNA were still detected for oysters reared in condition 1 , with 5 out of 9 individuals presenting more than $10^{3}$ DNA copies per mg. Oysters appeared to recover from OsHV-1 infection in conditions 2 and 3 , as only 1 individual out of 9 had more than 10 virus DNA copies in condition 3.

\subsection{Gene expression}

\subsubsection{Exp. 1.}

Out of the 12 genes whose expression was studied in Exp. 1, 5 appeared significantly impacted by the experimental treatment. The mRNA levels of $d 1$ and socs appeared significantly lower, by 0.6 and 0.8 times, respectively, for oysters injected with virulent inoculum compared with control oysters at day $2\left(d 1: F_{1,113}=10.3, P=0.0018\right.$; socs: $\left.F_{1,113}=5.82, P=0.0175\right)$ (Fig. $3 \mathrm{~A}$ and $3 C$ ). The quantity of these transcripts increased through the trial for inoculated oysters and became non-significantly different from control oysters from day 7. In contrast, Cu/Znsod mRNA level appeared 1.5 times higher for inoculated oysters compared with control oysters for the experiment as a whole (Cu/Znsod: $\left.\mathrm{F}_{1,113}=4.49, \mathrm{P}=0.036\right)$ (Fig. 3E). 
Secondly, expression levels of $n p y / f r, i k B 2$ and socs differed significantly among the classes of OsHV-1 infection (npy/fr: $\mathrm{F}_{4,113}=2.86, \mathrm{P}=0.029$; ikB2: $\mathrm{F}_{4,113}=9.72, \mathrm{P}<0.0001$; socs: $\mathrm{F}_{4,113}=$ $3.36, P=0.012)$. For $n p y / f r$, estimated LS means for $\log \left(D D C t_{\text {npyfr }}+1\right)$ regularly decreased from $0.923 \pm 0.03$ for individuals falling into the first class of viral infection, to $0.511 \pm 0.061$ for the heavily infected oysters (i.e. class 5) (Fig. 3B). Socs and ikB2 mRNA levels tended to increase in relation to OsHV-1 infection (Fig. 3D and 3F). LS means for $\log \left(\mathrm{DDCt}_{\mathrm{likB} 2}+1\right)$ increased from $0.694 \pm 0.042$ for class 0 to $1.595 \pm 0.221$ for class 4 ; $\log \left(D_{D C} t_{\text {socs }}+1\right)$ increased from $0.623 \pm$ 0.018 for class 0 to $0.956 \pm 0.094$ for class 4 .

\subsubsection{Exp. 2.}

Out of the 14 genes whose expression levels were quantified in Exp. 2, eight showed differential mRNA levels depending on rearing conditions (d1, tcte, bcl, Cu/Znsod, Ecsod) and/or OsHV-1 load (tpo, ikB2, tcte, Ecsod, cat). mRNA level of $d 1$ was lowest in baskets inside the farming area (condition 1) and intermediate on ropes (condition 2), therefore being negatively associated with mortality, even considering a slight increase of $d 1 \mathrm{mRNA}$ level that occurred over time (Fig. 4A). For tcte and bcl, a slight over-expression was detected in condition 3, which coincided with low OsHV-1 prevalence and the absence of mortality, even though their mRNA levels also varied significantly according to sampling date (Fig. 4C and 4E). The two superoxide dismutase genes, Cu/Znsod and Ecsod exhibited highly variable expression patterns over time and conditions (Fig. 4G and 4I), with significant effects of condition $\times$ day on Cu/Znsod mRNA level $\left(\mathrm{F}_{4,79}=2.84, \mathrm{P}=0.031\right)$ and of condition and condition $\times$ day on Ecsod mRNA level (condition: $\mathrm{F}_{2,79}=3.50, \mathrm{P}=0.036$ and condition $\times$ day: $\mathrm{F}_{4,79}=2.55 ; \mathrm{P}=0.047$ ). For $\mathrm{Cu} / \mathrm{Znsod}$, therefore, no consistent trend was shown between mRNA levels and virus load or mortality.

Tpo, ikB2, tcte, Ecsod and cat exhibited significant variations of mRNA levels depending on discrete classes of OsHV-1 load (tpo: $\mathrm{F}_{6,79}=2.76, \mathrm{P}=0.019 ;$; $k B 2: \mathrm{F}_{6,79}=10.87, \mathrm{P}<0.0001$; tcte: $\mathrm{F}_{6,79}=2.38, \mathrm{P}=0.038 ;$ Ecsod: $\mathrm{F}_{6,79}=9.04, \mathrm{P}<0.0001 ;$ cat: $\mathrm{F}_{6,79}=2.41, \mathrm{P}=0.036$ ). First, tpo and $i k B 2$ expression monotony increased with virus load in oyster tissues: $\log \left(\mathrm{DDC}_{\mathrm{tpo}}+1\right)$ increased from $0.657 \pm 0.05$ for class 1 to $1.481 \pm 0.219$ for class 7 , while $\log \left(\mathrm{DDCt}_{\mathrm{ikB} 2}+1\right)$ increased from $0.619 \pm 0.034$ to $1.616 \pm 0.148$ (Fig. 4B and 4F). Second, tcte, cat and Ecsod expression slightly increased in relation to virus load until class 5 (Fig. 4D, 4H and 4J). Then, $\log \left(\mathrm{DDCt}_{\mathrm{tcte}}+1\right)$ decreased from $0.854 \pm 0.142$ for class 5 to $0.552 \pm 0.169$ for class 6 . At the same time, $\log \left(\mathrm{DDCt}_{\mathrm{Ecsod}}+1\right)$ decreased from $0.770 \pm 0.190$ for class 5 to $0.299 \pm 0.092$ for class 6 , and $\log \left(\mathrm{DDCt}_{\mathrm{cat}}+1\right)$ decreased from $0.878 \pm 0.244$ for class 5 to $0.333 \pm 0.118$ for class 6.

\section{Discussion}

All the candidate genes tested in the present study had previously been suggested as associated with resistance to summer mortality through transcriptomic comparisons of lines selected to be resistant or susceptible (Huvet et al., 2004; Fleury et al., 2010; Fleury and Huvet, 2012). In our study, ten of these 17 candidates showed significant variation of their expression in response to virus load and/or rearing conditions with differing mortality, respectively. The putative role of these 10 genes (thyroid peroxidase, T-complex-associated testis-expressed protein, B-cell lymphoma/leukemia, suppressor of cytokine signaling, superoxide dismutase [CuZn], NF-kappa-B inhibitor 2, Neuropeptide Y receptor, Dopamine receptor D1, Extracellular 
Superoxide dismutase [Cu-Zn], Catalase) was already discussed in depth by Fleury et al. (2010) and Fleury and Huvet (2012). Interestingly, these genes were different from those reported in a study targeting hemolymph of Pacific oysters and distinguishing oysters that survived the summer from individuals that suffered mortality in the field (Chaney and Gracey, 2011), and in another on response of hemocytes to OsHV-1 infection (Renault et al., 2011). As previously proposed by Chaney and Gracey (2011), such differences could be due to differences in genotype-associated expression traits, targeted tissues and/or environmental conditions. Such specific patterns of mRNA responses can indeed limit their usefulness for understanding the molecular bases of oyster resistance to summer mortality or lead to the necessity to combine results obtained under different environmental conditions. This is the reason why we combined results of previously published genome-wide mRNA profiling (Fleury et al., 2010; Fleury and Huvet, 2012) with those from the present study of candidate gene expression under controlled and field conditions.

Out of our 17 candidate genes, seven (oyster-gonadal-TgF $\beta$-like, prostaglandin E2 receptor, toll-like receptor, manganese superoxide dismutase, complement C1q-like, heat shock $70 \mathrm{kDa}$, CD109 antigen precursor) did not show any significant variation between conditions tested in our two experiments. However, ten genes presented significant variation in expression in at least one of our experiments. Among these particularly interesting candidates, extracellular $\mathrm{Cu} / \mathrm{Zn}$ superoxide dismutase (Ecsod) expression was found to significantly differ at once in response to OsHV-1 infection and rearing conditions in experiment 2. NF-KB inhibitor 2 (ikB2) showed a pattern of increasing expression in response to OsHV-1 load that appeared consistent between the two experiments. Dopamine receptor (d1) exhibited significant variation in response to both the inocula and rearing conditions, in laboratory and field testing, respectively. For these three genes, common and consistent targets have already been identified in response to Vibrio infections; these pathogens have also been implied in mortality outbreaks especially in adults (e.g. de Decker and Saulnier, 2011; de Lorgeril et al., 2011; Taris et al., 2009).

The antioxidant system, already suggested to be crucial in determining susceptibility or resistance to summer mortality (Lambert et al., 2007; Fleury et al., 2010), once again appeared important in our data. The plasma extracellular Cu/Znsod (Cg-Ecsod; Gonzalez et al., 2005) and, to a lesser extent, the Cu/Znsod localized in intracellular cytoplasmic compartments (Boutet et al., 2004) appeared to vary according to OsHV-1 load and rearing conditions. Pathogens are known to induce phagocytosis and to stimulate the production of reactive oxygen species (ROS) in the host. ROS can kill invading pathogens through the activation of the respiratory burst, but can also cause oxidative damage (Cutler, 1991). A greater capacity to detoxify the ROS, notably by SOD metalloenzymes, would contribute to host cellular protection by preventing oxidative damage and, hence, improve oyster survival. However, the complexity of this SOD system should be explored further, especially the respective roles of the two groups of SODs classified according to the metal in their active sites (copper/zinc or manganese SOD) and the extensive set of sod genes (10 presumed) in C. gigas genome (Zhang et al., 2012).

Our most interesting candidate is $C g / K B 2$. Its expression increased as a consequence of increasing viral load in the host tissues, both in the laboratory and field. CglkB2 codes for an inhibitor of the NF-kB pathway; its expression was mainly found in gonad and digestive gland of oysters and was demonstrated in vitro to be a natural inhibitor of NF-kB activity (Zhang et al., 2011), as with CglkB1 (Montagnani et al., 2008). IkBs are inhibitors that retain transcriptional activator proteins of the NF-KB family in the cytoplasm. During inflammatory responses, the phosphorylation of inhibitors of NF-KB leads to the dissociation of the inhibitor / NF-KB complex, 
which is therefore subsequently free to translocate to the nucleus, where it stimulates transcription of immune genes. Such a response to virus binding and entry was observed for herpes simplex virus type 1 (Hargett et al., 2006), where the activation of NF-kB occurs and is accompanied by a loss of IkB proteins. The over-expression of IKB, and subsequent regulation of the NF-KB/REL was understood by Zhang et al. (2011) as an immune response aimed at keeping balance between protecting the host and killing invading pathogens. An alternative hypothesis proposes that herpesviruses may have evolved to regulate the NF-kB pathway in order to utilize this host response to promote efficient virus replication (Hargett et al., 2006). From the positive correlation we found between CglkB2 mRNA level and virus load, we can postulate that $C g / K B 2$ might have a role in preventing, or promoting, oyster herpesvirus-like infection in C. gigas via immune modulation.

Finally, one other candidate was highlighted here: a dopamine receptor (d1) that was upregulated in conditions associated with strong survival, in agreement with its higher expression previously observed in resistant compared with susceptible oyster lines (Fleury et al., 2010). The dopamine ligand-receptor system plays a part in the regulation of allocation of energy, growth, reproduction and defense (Lacoste et al., 2001a,b). The studied EST is $100 \%$ identical to the dopamine receptor $d 1$ identified in Crassostrea angulata with a suggested important regulatory role in the early ovarian development and maturation stage (Yang et al., 2013). The relationship between reproductive effort and survival was first investigated from a quantitative genetics viewpoint (Ernande et al., 2004). More recently, several studies have suggested that a trade-off between reproductive effort and survival could be the consequence of the conflict between energetic requirement to ensure survival during the summer months and allocation to building and maintaining gonadic tissues (e.g. Samain et al., 2007; Huvet et al., 2010). However, since 2008, the mortality period has occurred earlier (April/May versus June/July along the French coasts), and mortality now occurs during germ cell maturation rather than at the ripe and spawning stages, suggesting that if the reproduction mechanisms are involved in mortality, they should be sought during early gamete development.

To conclude, this study evaluated the expression profiles of several candidate genes, previously identified using microarrays, to prioritize these genes and assess their value in determining resistance to summer mortality. Our results are based on mRNA levels and not protein nor activity levels. Hence further study will be required to assess the functional significance of the observed expression patterns. Then, considering the temperature threshold interacting in the mass mortalities of young oysters (Pernet et al., 2012), knowledge of their temperaturedependent expression patterns would be a valuable information for addressing their implication in this syndrome.

Among the tested genes, Cg-Ecsod, CglkB2 and $d 1$ appeared to be candidates of particular interest. As first starting point, more specific and precise individual investigation of $\mathrm{Cg} / \mathrm{KB} 2$ is now needed in the context of response to pathogenic infections, and to elucidate its role using functional studies such as RNA interference, now available in oyster (Fabioux et al., 2009). This functional approach would be clearly more informative if performed on lines of oysters selected for resistance or susceptibility to mass mortality to test if switching off candidate genes may promote survival knock-down phenotype. 


\section{Acknowledgements}

This study was conducted as part of the GIS Europole Mer "OxyGenes" project. The authors are indebted to C. Fabioux, E. Fleury, M.J. Garet-Delmas, S. Trancard, P. Le Gall and J.Y. Daniel (best wishes for a long and enjoyable retirement) for their helpful assistance. We thank all the staff of Ifremer LPI (Brest) and LER/LR (Sète) for rearing the oysters and H. McCombie for her help with editing the English.

\section{References}

Boudry, P., Dégremont, L., Haffray, P., 2008. The genetic basis of summer mortality in Pacific oyster spat and potential for improving survival by selective breeding in France. In Samain JF. \& McCombie H. (eds): Summer mortality of Pacific oyster Crassostrea gigas - The Morest Project. Quae Editions, Versailles, France, pp.153-196.

Boutet, I., Tanguy, A., Moraga, D., 2004. Response of the Pacific oyster Crassostrea gigas to hydrocarbon contamination under experimental conditions. Gene 329, 147-57.

Boutet, I., Tanguy, A., Rousseau, S., Auffret, M., Moraga, D., 2003. Molecular identification and expression of heat shock cognate 70 (hsc70) and heat shock protein 70 (hsp70) genes in the Pacific oyster Crassostrea gigas. Cell Stress Chaperones 8, 76-85.

Chaney, M.L., Gracey, A.Y., 2011. Mass mortality in Pacific oysters is associated with a specific gene expression signature. Mol. Ecol. 20, 2942-54.

Cutler, R.G., 1991. Human longevity and aging: Possible role of reactive oxygen species. Ann. NY Acad. Sci. 621, 1-28.

de Decker, S., Saulnier, D., 2011. Vibriosis induced by experimental cohabitation in Crassostrea gigas: evidence of early infection and down-expression of immune-related genes. Fish Shellfish Immunol. 30, 691-9.

De Lorgeril, J., Zenagui, R., Rosa Rafael, D., Piquemal, D., Bachère, E., 2011. Whole transcriptome profiling of successfull immune response to Vibrio infections in the oyster Crassostrea gigas by Digital Gene Expression analysis. PloS ONE 6, e23142.

Dégremont, L., 2011. Evidence of herpesvirus (OsHV-1) resistance in juvenile Crassostrea gigas selected for high resistance to the summer mortality phenomenon. Aquaculture 317, 94-98.

Dégremont, L., Ernande, B., Bédier, E., Boudry, P., 2007. Summer mortality of hatcheryproduced Pacific oyster spat (Crassostrea gigas). I. Estimation of genetic parameters for survival and growth. Aquaculture 262, 41-53.

Dégremont, L., Bédier, E., Boudry, P., 2010. Summer mortality of hatchery-produced Pacific oyster spat (Crassostrea gigas). II. Response to selection for survival and its influence on growth and yield. Aquaculture 299, 21-29.

Ernande, B., Boudry, P., Clobert, J., Haure, J., 2004. Plasticity in resource allocation based life history traits in the Pacific oyster, Crassostrea gigas. I. Spatial variation in food abundance. J. Evol. Biol. 17, 342-56.

Fabioux, C., Corporeau, C., Quillien, V., Favrel, P., Huvet, A., 2009. In vivo RNA interference in oyster: vasa silencing inhbits germ cell development. FEBS J. 276, 2566-73.

Fabioux, C., Huvet, A., Lelong, C., Robert, R., Pouvreau, S., Daniel, J.Y., Minguant, C., Le Pennec, M., 2004. Oyster vasa-like gene as a marker of the germline cell development in Crassostrea gigas. Biochem. Biophys. Res. Commun. 320, 592-8.

Fleury, E., Fabioux, C., Lelong, C., Favrel, P., Huvet, A., 2008. Characterization of a gonadspecific transforming growth factor-beta superfamily member differentially expressed during the reproductive cycle of the oyster Crassostrea gigas. Gene 410, 187-96. 
Fleury, E., Moal, J., Boulo, V., Daniel, J.Y., Mazurais, D., Henault, A., Corporeau, C., Boudry, P., Favrel, P., Huvet, A., 2010. Micro-array based identification of gonad transcripts differentially expressed between lines of Pacific oyster selected to be resistant or susceptible to summer mortality. Mar. Biotechnol. 12, 326-39.

Fleury, E., Huvet, A., 2012. Microarray analysis highlights immune response of Pacific oysters as a determinant of resistance to summer mortality syndrome. Mar. Biotechnol. 14, 20317.

Gonzalez, M., Romestand, B., Fievet, J., Huvet, A., Lebart, M.C., Gueguen, Y., Bachère, E., 2005. Evidence in oyster of a plasma extracellular superoxide dismutase which binds LPS. Biochem. Biophys. Res. Commun. 338, 1089-97.

Hargett, D., Rice, S., Bachenheimer, SL., 2006. Herpes simplex virus type 1 ICP27-dependent activation of NF-kB. J Virol. 80, 10565-78.

Huvet, A., Herpin, A., Dégremont, L., Labreuche, Y., Samain, J.F., Cunningham, C., 2004. The identification of genes from the oyster Crassostrea gigas that are differentially expressed in progeny exhibiting opposed susceptibility to summer mortality. Gene 343, 211-20.

Huvet, A., Normand, J., Fleury, E., Quillien, V., Fabioux, C., Boudry, P., 2010. Reproductive effort of Pacific oysters: a trait associated with susceptibility to summer mortality. Aquaculture 304, 95-99.

Huvet, A., Fleury, E., Corporeau, C., Quillien, V., Daniel, J.Y., Riviere, G., Boudry, P., Fabioux, C., 2012. In vivo RNA interference of a gonad-specific transforming growth factor- $\beta$ in the Pacific oyster Crassostrea gigas. Mar. Biotechnol. 14, 402-10.

Jo, P.G., Choi, Y.K., Choi, C.Y., 2008. Cloning and mRNA expression of antioxidant enzymes in the Pacific oyster, Crassostrea gigas in response to cadmium exposure. Comp. Biochem. Physiol. 147, 460-9.

Jolivel, A., Fleury, E., 2012. Analyse statistique des données de mortalité d'huîtres acquises par l'Observatoire National Conchylicole (RESCO). Rapport Ifremer. http://archimer.ifremer.fr/doc/00130/24095/22078.pdf. Accessed May 30, 2013.

Lacoste, A., Jalabert, F., Malham, S.K., Cueff, A., Poulet, S.A., 2001a. Stress and stressinduced neuroendocrine changes increase the susceptibility of juvenile oysters (Crassostrea gigas) to Vibrio splendidus. Appl Environ Microbiol 67, 2304-9.

Lacoste, A., Malham, S.A., Cueff, A., Jalabert, F., Gelebart, F., Poulet, S.A., 2001b. Evidence for a form of adrenergic response to stress in the mollusc Crassostrea gigas. J. Exp. Biol. 204, 1247-55.

Lambert, C., Soudant, P., Delaporte, M., Moal, J., Boudry, P., Jean, F., Huvet, A., Samain, J.F., 2007. Hemocyte characteristics in families of oysters, Crassostrea gigas, selected for differential survival during summer and reared in three sites. Aquaculture 270, 276-88.

Lang, R.P., Bayne, C.J., Camara, M.D., Cunningham, C., Jenny, M.J., Langdon, C.J., 2009. Transcriptome profiling of selectively bred Pacific oyster Crassostrea gigas families that differ in tolerance of heat shock. Mar. Biotechnol. 11, 650-68.

Montagnani, C., Labreuche, Y., Escoubas, J.M., 2008. Cg-lkappaB, a new member of the IkappaB protein family characterized in the pacific oyster Crassostrea gigas. Dev. Comp. Immunol. 32, 182-90.

Park, M.S., Jo, P.G., Choi, Y.K., An, K.W., Choi, C.Y., 2009. Characterization and mRNA expression of Mn-SOD and physiological responses to stresses in the Pacific oyster Crassostrea gigas. Mar. Biol. Res. 5, 451-61.

Pfaffl, M.W., 2001. A new mathematical model for relative quantification in real-time RT-PCR. Nucleic Acids Res. 29, 2002-7.

Pepin, J.F., Riou, A., Renault, T., 2008. Rapid and sensitive detection of ostreid herpesvirus 1 in oyster samples by real-time PCR. J. Virol. Methods 149, 269-76.

Pernet, F., Barret, J., Le Gall, P., Corporeau, C., Dégremont, L., Lagarde, F., Pepin, J.F., Keck, N., 2012. Mass mortalities of Pacific oysters Crassostrea gigas reflect infectious 
diseases and vary with farming practices in the Mediterranean Thau lagoon, France. Aquacult. Env. Interac. 2, 215-37.

Renault, T., Faury, N., Barbosa-Solomieu, V., Moreau, K., 2011. Suppression substractive hybridisation (SSH) and real time PCR reveal differential gene expression in the Pacific cupped oyster, Crassostrea gigas, challenged with Ostreid herpesvirus 1. Dev. Comp. Immunol. 35, 725-35.

Renault, T., Moreau, P., Faury, N., Pepin, J.F., Segarra, A., Webb, S., 2012. Analysis of clinical ostreid herpesvirus 1 (Malacoherpesviridae) specimens by sequencing amplified fragments from three virus genome areas. J Virol. 86, 5942-7.

Samain, J.F., Dégremont, L., Soletchnik, P., Haure, J., Bédier, E., Ropert, M., Moal, J., Huvet, A., Bacca, H., Van Wormhoudt, A. et al., 2007. Genetically based resistance to summer mortality in the Pacific oyster (Crassostrea gigas) and its relationship with physiological, immunological characteristics and infection process. Aquaculture 268, 227-43.

Samain, J.F., McCombie, H., 2008. Summer Mortality of Pacific Oyster Crassostrea gigas. Ed. Ifremer/Quae, Versailles, France.

Saulnier, D., de Decker, S., Haffner, P., Cobret, L., Robert, M., Garcia, C., 2010. A Large-Scale Epidemiological Study to Identify Bacteria Pathogenic to Pacific Oyster Crassostrea gigas and Correlation between Virulence and Metalloprotease-like Activity. Microb. Ecol. 59, 787-98.

Sauvage, C., Boudry, P., de Koning, D.J., Haley, C.S., Heurtebise, S., Lapègue, S., 2010. QTL for resistance to summer mortality and OsHV-1 load in the Pacific oyster (Crassostrea gigas). Anim. Genet. 41, 390-9.

Schikorski, D., Faury, N., Pepin, J.F., Saulnier, D., Tourbiez, D., Renault, T., 2011a. Experimental ostreid herpesvirus 1 infection of the Pacific oyster Crassostrea gigas: kinetics of virus DNA detection by q-PCR in seawater and in oyster samples. Virus Res. 155, 28-34.

Schikorski, D., Renault, T., Saulnier, D., Faury, N., Moreau, P., Pépin J.F., 2011b. Experimental infection of Pacific oyster Crassostrea gigas spat by ostreid herpesvirus 1: demonstration of oyster spat susceptibility. Vet. Res. 42, 27.

Segarra, A., Pepin, J.F., Arzul, I., Morga, B., Faury, N., Renault, T., 2010. Detection and description of a particular Ostreid herpesvirus 1 genotype associated with massive mortality outbreaks of Pacific oysters, Crassostrea gigas, in France in 2008. Vir. Res. $153,92-9$.

Suquet, M., de Kermoysan, G., Araya, R.G., Queau, I., Lebrun, L., Le Souchu, P., Mingant, C., 2009. Anesthesia in Pacific oyster, Crassostrea gigas. Aquat. Living Resour. 22, 29-34.

Taris, N., Lang, R.P., Reno, P.W., Camara, M.D., 2009. Transcriptome response of the Pacific oyster (Crassostrea gigas) to infection with Vibrio tubiashii using cDNA AFLP differential display. Anim. Genet. 40, 663-77.

Yang, B., Ni, J., Zeng, Z., Shi, B., You, W., Ke, C., 2013. Cloning and characterization of the dopamine like receptor in the oyster Crassostrea angulata: Expression during the ovarian cycle. Comp. Biochem. Physiol. 164, 168-75.

Zelterman D., 2002. Advanced Log-linear models using SAS. SAS Institute Inc., Cary, NC, USA, $189 \mathrm{pp}$.

Zhang, G., Fang, X., Guo, X., Li, L., Luo, R., Xu, F., Yang, P., Zhang, L., Wang, X., Qi H, Xiong, Z., Que, H., et al., 2012. The oyster genome reveals stress adaptation and complexity of shell formation. Nature 490, 49-54.

Zhang, Y., He, X.C., Yu, Z.N., 2011. Two homologues of inhibitor of NF-kappa B (I kappa B) are involved in the immune defense of the Pacific oyster, Crassostrea gigas. Fish Shellfish Immun. 30, 1354-61. 
Figure 1. Proportion of individuals per class of OsHV-1 load in experiment 1, by inoculum (virulent or control) and day post injection.

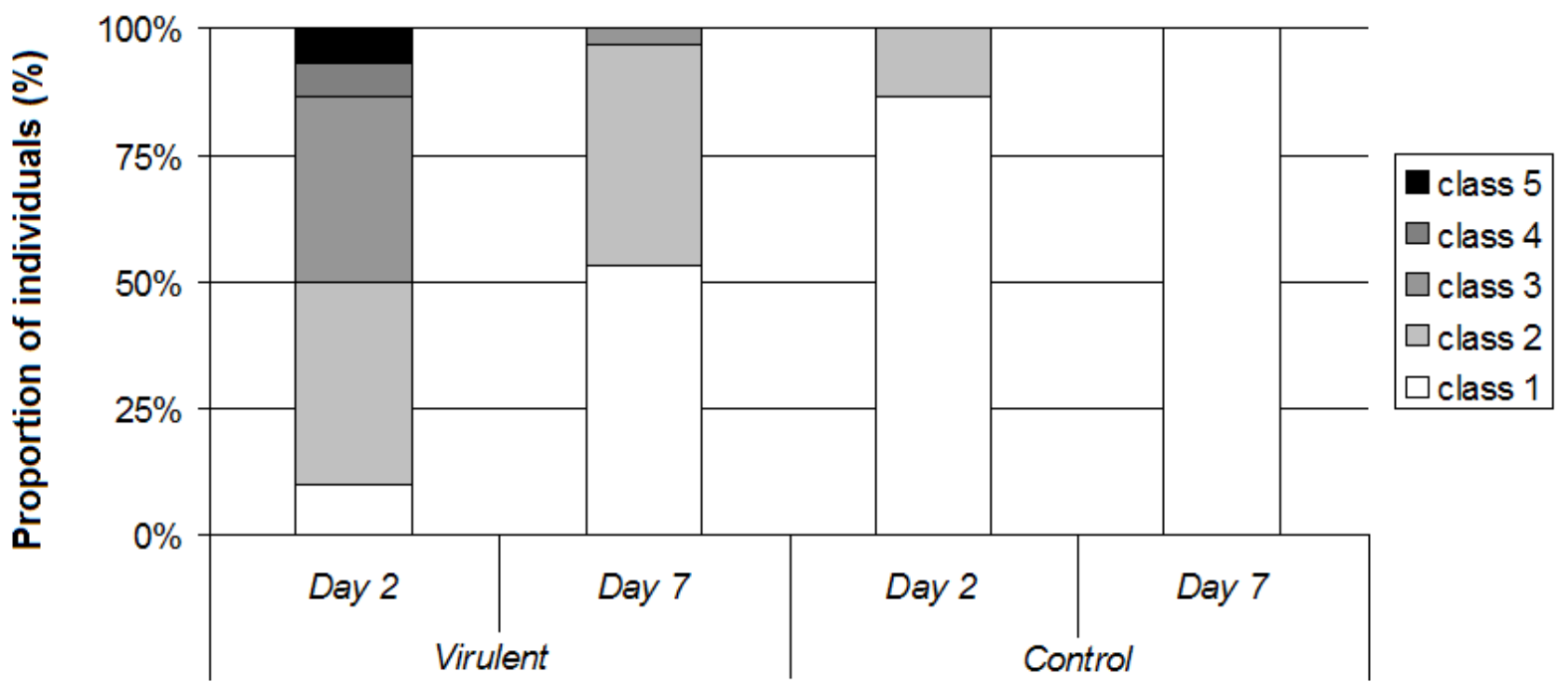

Experiment 1 : Inoculum x post-injection day

Figure 2. Proportion of individuals per class of OsHV-1 load in experiment 2, by rearing condition and day post deployment.

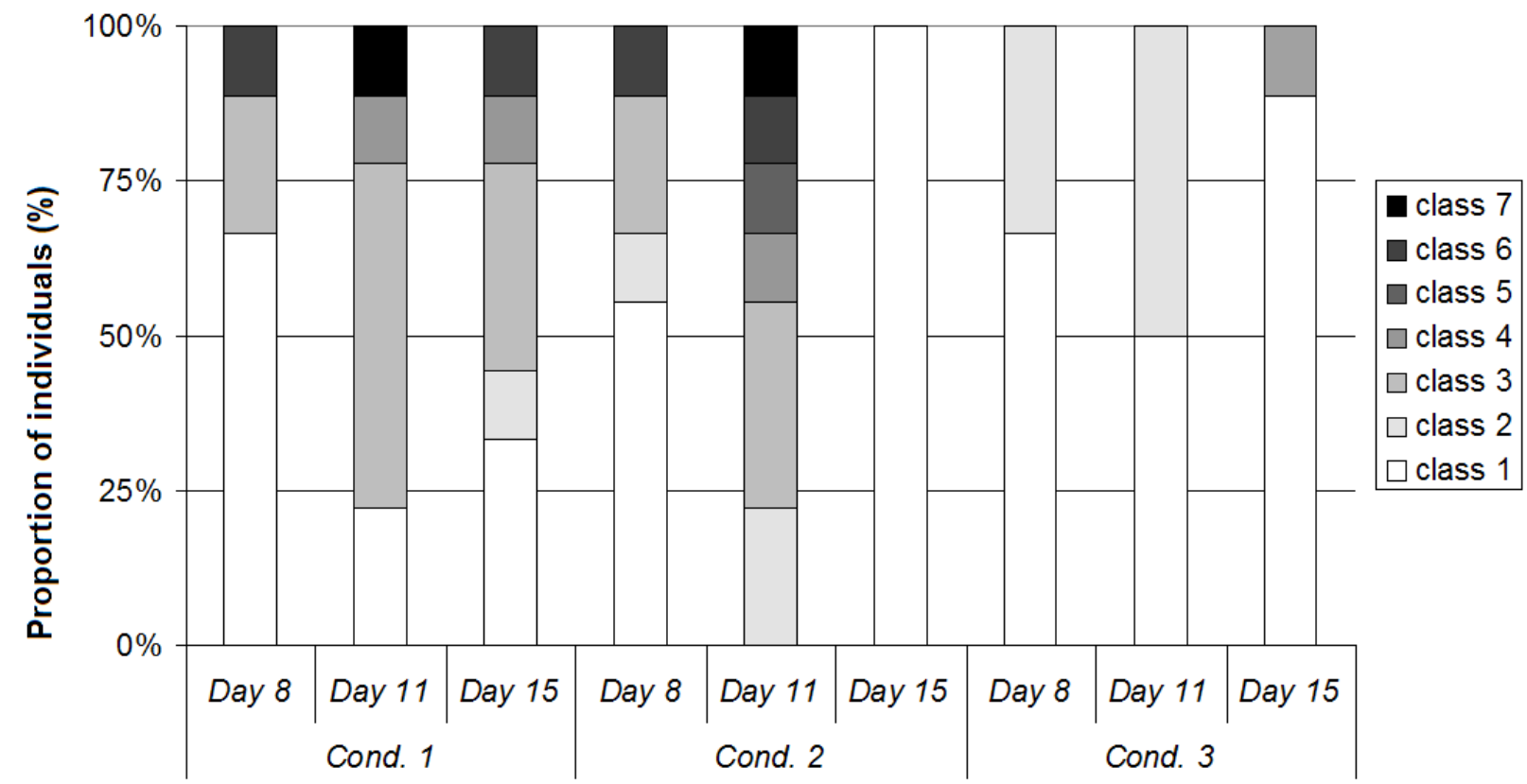

Experiment 2 : Rearing condition $\mathrm{x}$ date of sampling 
Figure 3. Gene expression in experiment 1, LS means and standard errors from GLM models. Histograms on the left-hand side describe day post-injection $\times$ inoculum effects on gene expression for $d 1(\mathrm{~A})$, socs $(\mathrm{C})$ and $\mathrm{Cu} / \mathrm{Znsod}(\mathrm{E})$. Black bars represent virulent inoculum and grey bars represent the control. Histograms on the right-hand side describe gene expression by class of OsHV-1 load for npy/fr (B), socs (D) and ikB2 (F). A common letter for two groups means that post-hoc tests detected no significant differences for gene expression levels between them.

A

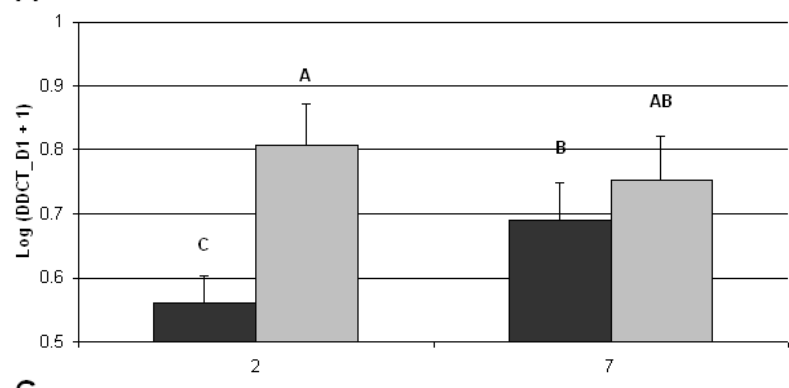

C

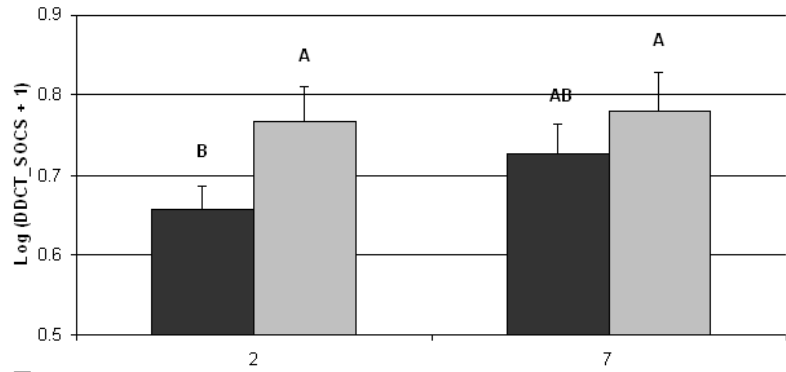

E

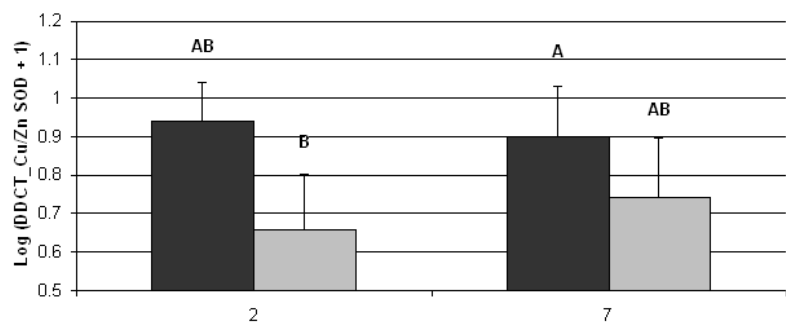

Day post-injection

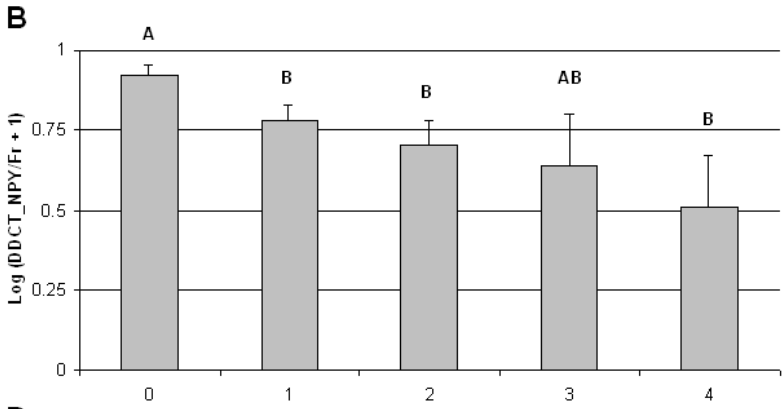

D
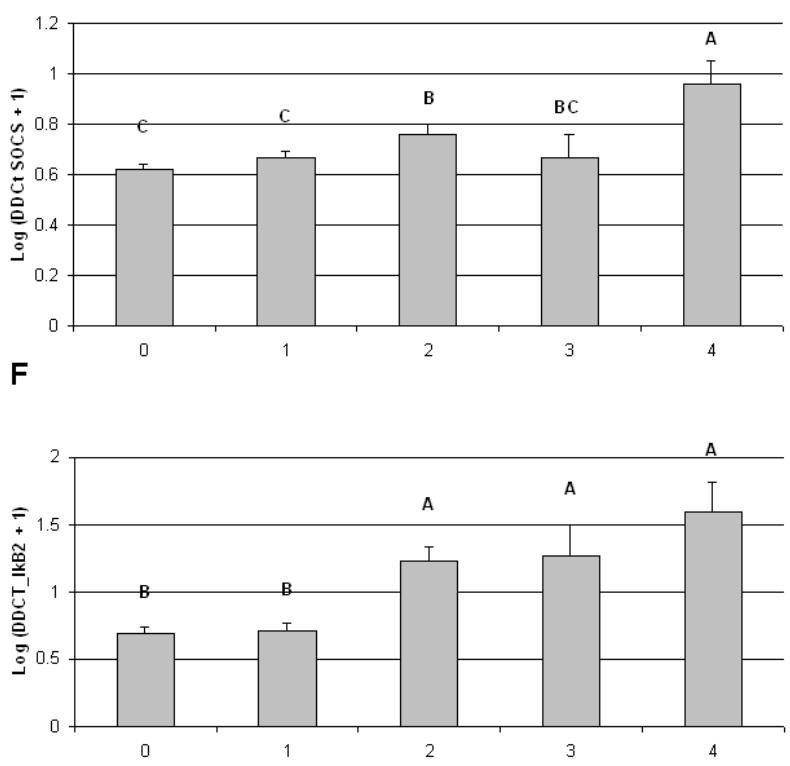

Class OsHV-1

Figure 4. Gene expression in experiment 2, LS means and standard errors from GLM models. Histograms on the left side describe day after deployment $\times$ rearing condition effect on gene expression for $d 1(\mathrm{~A})$, tcte $(\mathrm{C}), b c \mathrm{(E}), \mathrm{Cu} / \mathrm{Znsod}(\mathrm{G})$ and Ecsod (I), black bars represent rearing condition 1 (baskets inside the farming area), grey bars represent rearing condition 2 (ropes) and white bars represent rearing condition 3 (baskets outside the farming area). Histograms on the right-hand side describe gene expression by class of OsHV-1 load for tpo (B), tcte (D), ikB2 $(F)$, cat $(H)$ and Ecsod $(J)$. A common letter for two groups means that post-hoc tests detected no significant differences for gene expression levels between them. 

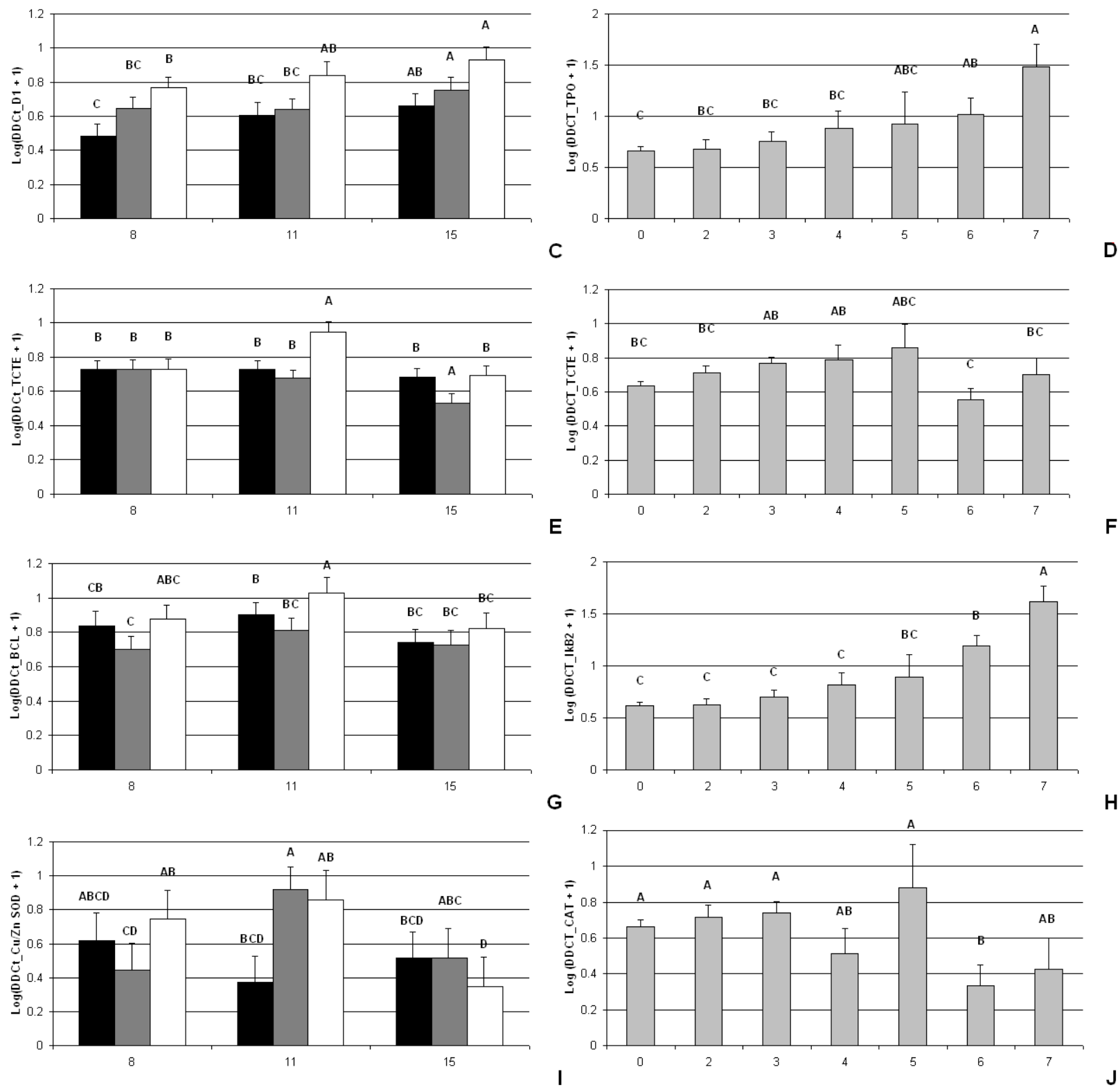

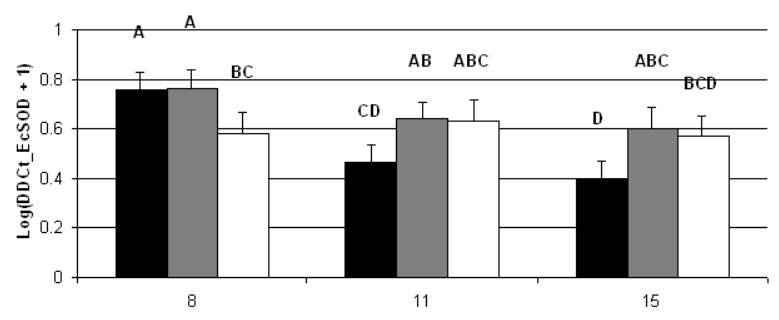

Day after deployment

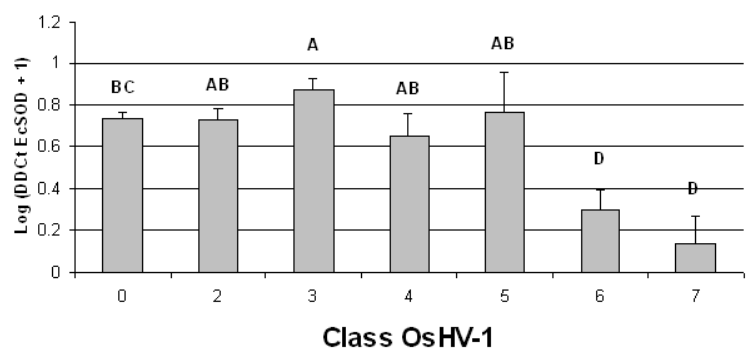


Table S1. Sense and anti-sense sequences of primer pairs for real-time PCR analysis, used to amplify cDNA of 17 candidate ESTs. PCR efficiencies were determined for each primer pair by determining the slopes of standard curves obtained from serial dilution analysis of the cDNA reference. GenBank accession numbers are indicated. The original publication of each EST/mRNA is also given.

\begin{tabular}{|c|c|c|c|c|c|}
\hline GenBank \# & EST name & Abbreviation & $\begin{array}{l}\text { Forward primer } \\
\text { Reverse primer }\end{array}$ & $\begin{array}{l}\text { Efficiency } \\
(\%)\end{array}$ & Reference \\
\hline AM854726 & Toll-like receptor & TLR & $\begin{array}{l}\text { 5'-GACCTCCGATGGTTCAGAGA-3' } \\
\text { 5'-TGCATCGGGAGAATTACACA-3 }\end{array}$ & 99,9 & $\begin{array}{l}\text { Fleury and } \\
\text { Huvet } 2012\end{array}$ \\
\hline AM856775 & $\begin{array}{l}\text { Prostaglandin } \\
\text { E2 receptor }\end{array}$ & Ep2 & $\begin{array}{l}\text { 5'-TAGGAGTGATGCTGGCAGTG-3' } \\
\text { 5'-CCGCCATATAATCGCAAACT-3' }\end{array}$ & 100.6 & $\begin{array}{l}\text { Taris et al. } \\
2009\end{array}$ \\
\hline CU682412 & $\begin{array}{l}\text { Thyroid } \\
\text { peroxidase }\end{array}$ & TPO & $\begin{array}{l}\text { 5'-GCCAAACCTCGCCTACCTTC-3' } \\
\text { 5'-GTGGAGTTGACGCGTGACATA-3' }\end{array}$ & 99.5 & $\begin{array}{l}\text { Lang et al. } \\
2009\end{array}$ \\
\hline AM858229 & $\begin{array}{l}\text { T-complex-associated } \\
\text { testis-expressed protein }\end{array}$ & TCTE & $\begin{array}{l}\text { 5'-GACTGTTTGCTGTTGGCTCA-3' } \\
\text { 5'-TCTGACTTTGTCGTCGTCCA-3' }\end{array}$ & 100.4 & $\begin{array}{l}\text { Fleury and } \\
\text { Huvet } 2012\end{array}$ \\
\hline CU681745 & $\begin{array}{l}\text { B-cell } \\
\text { Iymphoma/leukemia }\end{array}$ & $\mathrm{BCL}$ & $\begin{array}{l}\text { 5'-TAAACACCTGAATCCCCAAGA-3' } \\
\text { 5'-GCCGTTTACTGGTCACTTCTG-3' }\end{array}$ & 100.2 & $\begin{array}{l}\text { Fleury and } \\
\text { Huvet } 2012\end{array}$ \\
\hline AM853235 & $\begin{array}{l}\text { Complement } \\
\text { C1q-like protein }\end{array}$ & $\mathrm{C} 1 \mathrm{q}$ & $\begin{array}{l}\text { 5'- ATACACTTGCACGCCAGGAT -3' } \\
\text { 5'- GCGGAGTTACCAGCATTAGC -3' }\end{array}$ & 100.3 & $\begin{array}{l}\text { Taris et al. } \\
2009\end{array}$ \\
\hline CU686145 & $\begin{array}{l}\text { Suppressor of } \\
\text { cytokine signaling }\end{array}$ & SOCS & $\begin{array}{l}\text { 5'-ATCAGCCGATTCATCCTCAG-3' } \\
\text { 5'-TGCTGGAATGTGTAGGCAAC-3' }\end{array}$ & 100 & $\begin{array}{l}\text { Fleury and } \\
\text { Huvet } 2012\end{array}$ \\
\hline AM856093 & $\begin{array}{l}\text { Superoxide } \\
\text { dismutase [Cu-Zn] }\end{array}$ & $\mathrm{Cu} / \mathrm{Zn}$ SOD & $\begin{array}{l}\text { 5'-TAACACCTGGACAGCATGGA-3' } \\
\text { 5'-TTAAAGTGGGCTCCAGCACT-3' }\end{array}$ & 99 & $\begin{array}{l}\text { Boutet et al. } \\
2004\end{array}$ \\
\hline AM856743 & $\begin{array}{l}\text { NF-kappa-B } \\
\text { inhibitor }\end{array}$ & IkB2 & $\begin{array}{l}\text { 5'-CAACGACAAACTGAGGCAGA-3' } \\
\text { 5'-CGTTATTTCGCCTTTGTGGT-3' }\end{array}$ & 100.1 & $\begin{array}{l}\text { Zhang et al. } \\
2011\end{array}$ \\
\hline AM856249 & $\begin{array}{l}\text { Neuropeptide } \\
\text { Y receptor }\end{array}$ & NPY/Fr & $\begin{array}{l}\text { 5'-GTGGCTTGTGGGCT ATTGT-3' } \\
\text { 5'-CTGAAATCCGAATGGACGAC-3' }\end{array}$ & 101.9 & $\begin{array}{l}\text { Fleury et al. } \\
2010\end{array}$ \\
\hline AM856765 & $\begin{array}{l}\text { Oyster-gonadal- } \\
\text { TGF } \beta \text {-like }\end{array}$ & ogTGF $\beta$ & $\begin{array}{l}\text { 5'-TTGGACATCAGGGAAATTCTG-3' } \\
\text { 5'-CCAAACGAAACGACAGGAAC-3' }\end{array}$ & 98.7 & $\begin{array}{l}\text { Fleury et al. } \\
2008\end{array}$ \\
\hline FP091069 & Dopamine receptor & D1 & $\begin{array}{l}\text { 5'-ATCACGAGTAAGGCGACGAG-3' } \\
\text { 5'-CGGTGTTTGGTAATGTGCTG-3' }\end{array}$ & 101.3 & $\begin{array}{l}\text { Fleury et al. } \\
2010\end{array}$ \\
\hline CX069254 & $\begin{array}{l}\text { CD109 } \\
\text { antigen precursor }\end{array}$ & CD109 & $\begin{array}{l}\text { 5'-CTGGTTGGCTGGCTCATAGT-3' } \\
\text { 5'-ATTTCCACCACTCCAACCTG-3' }\end{array}$ & 98.8 & $\begin{array}{l}\text { Fleury et al. } \\
2010\end{array}$ \\
\hline CU681762 & $\begin{array}{l}\text { Extracellular } \\
\text { superoxide } \\
\text { dismutase }[\mathrm{Cu}-\mathrm{Zn}]\end{array}$ & EcSOD & $\begin{array}{l}\text { 5'-CTTCATGCCAGGCAACCT-3' } \\
\text { 5'-TGACGTTGAATCCGGTCA-3' }\end{array}$ & 101.4 & $\begin{array}{l}\text { Gonzalez et } \\
\text { al. } 2005\end{array}$ \\
\hline CU681620 & $\begin{array}{l}\text { Manganese } \\
\text { superoxide dismutase }\end{array}$ & MnSOD & $\begin{array}{l}\text { 5'-AGTCTGGTCGCACATTCTTGT-3' } \\
\text { 5'-CATGTGCCAATCAAGATCCTC-3' }\end{array}$ & 101.4 & $\begin{array}{l}\text { Park et al. } \\
2009\end{array}$ \\
\hline AM854673 & $\begin{array}{l}\text { Heat shock } \\
70 \mathrm{kDa}\end{array}$ & Hsp70 & $\begin{array}{l}\text { 5'-CCTGCAATATGGAGTGATTCG-3' } \\
\text { 5'-CTTCCGGTTCATAAGCCATC-3' }\end{array}$ & 100.5 & $\begin{array}{l}\text { Boutet et al. } \\
2003\end{array}$ \\
\hline AM853618 & Catalase & CAT & $\begin{array}{l}\text { 5'-CACCGGACGGTTATAGGAGA-3' } \\
\text { 5'-TGCAGAAGACTGGTTTGTCG-3' }\end{array}$ & 100.8 & Jo et al. 2008 \\
\hline
\end{tabular}

